\title{
IMPACT OF TELECOMMUNICATION INFRASTRUCTURE, MARKET SIZE, TRADE OPENNESS AND LABOR FORCE ON FOREIGN DIRECT INVESTMENT IN ASEAN
}

\begin{abstract}
Anis Wahyu Meidayati*1 (D)
${ }^{1}$ Faculty Economics and Business, Universitas Airlangga, Indonesia 2015 from 10 countries in ASEAN. The results showed simultaneously and partially telecommunication infrastructure, market size, trade openness, and labor force variable have significant relationship with FDI inflows in ASEAN countries.
\end{abstract}

\section{ARTICLE INFO}

Received: September $1^{\text {st }}, 2017$ Revised: November $2^{\text {nd }}, 2017$ Accepted: November $17^{\text {th }}, 2017$ Online: December $27^{\text {th }}, 2017$

*Correspondence:

Anis Wahyu Meidayati E-mail: jurnaleconomi@gmail.com

Keywords: Telecommunication Infrastructure, Market Size, Trade Openness, Labor Force, FDI

JEL: L96, L11, B17, J21, F21

To cite this document: Meidayati, A.W. (2017). Impact of Telecommunication Infrastructure, Market Size, Trade Openness and Labor Force on Foreign Direct Investment In ASEAN. JDE (Journal of Developing Economies), 2(2), 73-80

\section{Introduction}

Foreign Direct Investment (FDI) is widely viewed as one of the instruments to improve the growth of developing country economies through the entry of multinational companies that exert spillover effect on host country. The main forms of spillover effects include technology transfer that directly contributes to increased capital productivity, technological developments, skills and managerial transfers and global market access (Suleiman et al., 2013). FDI is an important instrument for ASEAN member countries to boost economic growth and to help foster sustainable investment growth in ASEAN member countries. Conceptually, the choice of foreign investors to invest FDI in a country is affected by the condition of the host country (pull factors) as well as the conditions and strategies of foreign investors (Rehman et al., 2011). Pull factors of FDI entry consist of market conditions, infrastructure, resource availability, competitiveness, trade and industry policies and FDI liberalization policies (in the form of investment incentives). Push factors include investment strategies and production strategies from investors, as well as risk perceptions of the host country. 
The role of infrastructure in the host country is important in influencing foreign investors to invest. The availability and quality of supporting infrastructure is essential for the smooth operation of the production of multinational enterprises. Better infrastructure can significantly reduce high costs (Calderón \& Servén, 2008). These conditions affect the decision of foreign investors to invest FDI into the country. Low quality of infrastructure leads to increased transaction costs and limited access to local markets and global markets that cause foreign investors unwilling to invest FDI in host countries (Calderón \& Servén, 2008).

The complex nature of the high communication requirements between headquarters and subsidiaries demonstrates the dynamic relationship between telecommunications infrastructure, information flow and economic, financial, trade and other types of spatial interactions. So that an increasingly adequate telecommunications network will lower the cost of coordination between the company and its affiliates (Shah, 2014). In addition, improvements in the telecommunications infrastructure can increase the adoption of information and communication technologies that will generate the number of positive spillovers that potentially increase FDI inflows and economic growth (Shah, 2014). The benefits of spillovers supported by telecommunication infrastructure improvements will lead an enhance of global knowledge and innovation for a country. Therefore, telecommunication infrastructure also plays an important role in influencing the FDI inflow to ASEAN countries.

In order to attract foreign investors, a country with large market size have opportunity to attract more FDI inflows. The wide market size provides more opportunities to increase product sales as well as profits for foreign companies so that it attracts more FDI (Chakrabarti, 2001). In addition, trade openness will increase the FDI inflows. With a trade disclosure policy undertaken by a country can increase economic growth, improve prosperity, increase dynamic and static benefits, then generate new inflows of FDI. Another factor driving foreign investment is the labor force, where a country with a diverse workforce will invite many FDI (Sarna, 2005). Multinational companies in countries that do not have a skilled workforce and less innovation will gain less profit because they will produce less quality of output and lower competitiveness (Sarna, 2005).

This study is mainly conducted to investigate the factor affecting FDI in ASEAN countries. This study uses panel data from 2005 to 2015 and Random Effect Model (REM) for empirical estimations. The study is structured as follows: Section 2 provides the review of literature while analytical model is described in section 3 . Section 4 present the empirical findings and last section 5 concludes the study.

\section{Literature Review}

Foreign Direct Investment (FDI) is widely viewed as one of the instruments to improve the growth of developing country economies. FDI contributes to increase productivity, employment level, rise in export and indeed, and increased pace of transfer technology (Mughal \& Akram 2011). Berg \& Sellin (2004) argues that FDI is an overseas investment conducted by multinational enterprises (MNEs), which involves the active role of foreign investors in the management and operations of domestic firms. The literature of FDI began around the mid of last century for example by Vernon (1979), Huggins (2007) and Hymer (1960). Vernon (1979) claimed that foreign investment was based on product cycle, innovation, maturity product, and standardization. While Huggins (2007) explains that foreign direct investment will be made if the expected income is greater than the costs required for overseas supervision or overseas production and oversight costs are lower than the costs of domestic production and export cost export. Hymer (1960) confirmed that FDI is a direct effect of the imperfect markets. 
Capital flows move from one country to another due to the expectations of rates return in other countries (Appleyard et al., 2008:230). Large companies have some good knowledge or management that can be used to generate profits in other countries (Salvatore, 2007:423). Carbaugh (2008:306-307) explained that multinational company investing overseas because the company's domestic production level is sufficient for domestic demand so that the investment aims to increase production expansion. Market competition can also influence a multinational company's decision to invest abroad. Kurniati \& Prasmuka (2007) mentioned that FDI is motivated by resource seeking, market seeking, and efficiency seeking.

The investors' reason to invest their capital in developing countries depends on economic factors, such as the availability of skilled labor, production factors, natural resources, labor wages, and infrastructure (Botric, 2006). Grigg (2000) defined that Infrastructure as basic facilities/structures, equipment, installations built and needed for the functioning of social and economic systems of society. Todaro (2006:519) also defined that infrastructure as one of the important factors determining economic development.

Zeb et al., (2014) confirmed that the determinants of FDI comprise the availability of telecommunication infrastructure and trade openness in a country. In an analysis of the determinants of annual average inflows of FDI form year 1990 to 2012 in Pakistan, found that availability of telecommunication infrastructure contributes to productivity and economic development and thereby attract higher amount of FDI. Another research by Shah (2014) showed that telecommunication density approximated with the number of fixed line telephone and mobile cellular subscription or internet access possibilities in the host economy represents value added factors that led investors to choose a particular location. Novianti et al, (2014) mentioned that there are several benefits of telecommunication infrastructure support to economic and social development, including: (1) to encourage new investment, (2) to improve the connectivity between residents of a country, (3) to enhance the efficiency in resources allocation, (4) to facilitate the flow of ideas, goods, and services to give added values in economic and social activities.

The market size has also been considered as key variable in determining inward FDI. The market size of a country that shows the economic conditions and potential demand for domestic production is an important element in making a decision to perform FDI. Increase in the number of buyers will cause an increase in incoming FDI (Shah \& Khan, 2016). Market size has proven to be the most important determinant of FDI especially for foreign companies in order to looking for market expansion. The wide market size is necessary for efficiency in resources utilization and exploitation of larger economies of scale.

Mughal \& Akram (2011) found that market size as the most dominating positive impact factor to attract FDI in Pakistan. Although, Gharaibeh (2015) found that market size insignificant to attract FDI in Bahrain. This study showed that most of the foreign investor in Bahrain do not consider the size of the market in making decision to invest due to the low level of income in African countries. Foreign investment projects are directed towards a tradable sector so that the trade transparency of a country is one of the determinant factors in FDI decision making (Demirhan \& Masca 2008). The reduction in tariffs and duties on foreign goods and services, flexible government policies and low transaction costs positively contributes toward increasing inward FDI (Shah \& Khan, 2016). Gharaibeh (2015) concluded that trade openness has statistically significant relationship with FDI inflow. Similarly, Zeb et al, (2014) found that trade openness has significant impact on FDI in Pakistan.

Every company always try to make labor be able to give higher output so that work pro- 
ductivity is maximal and optimal. Work productivity for a company is a measure of success in running a business, because the high productivity of work will increase the company's profit and productivity (Umoru \& Yaqub 1987). Gharaibeh (2015) found that an increase in labor force will increases the amount of FDI inflow into the country. Although, Zeb et al. (2014) found that labor force has no significant impact to FDI in Pakistan.

\section{Methodology}

In order to investigate the impact of telecommunication infrastructure, market size, trade openness and labor force to foreign direct investment in ASEAN, panel random effect method is used. Although there are many factors that affect FDI in ASEAN, but four variables were taken under consideration in the present study. This model follows the research Zeb et al. (2014). The empirical estimation model is as follow:

$$
\operatorname{LnFDI}_{i t}=\alpha+\beta_{1} \operatorname{LnMS}_{i t}+\beta_{2} T_{i t}+\beta_{3} \operatorname{LnLF}_{i t}+\beta_{4} T_{E L E}+\varepsilon_{i t}
$$

Where, $\alpha$ is constant. Ln is used for natural logarithm. i represent countries from 1 to 10 , whereas the subscript $t$ represent time from 2005 to 2015. The dependent and all the independent variables are given in table 1.

Table 1: Variables Description, Symbols, Data Sources

\begin{tabular}{llll}
\hline variables & Proxy Used & Abbreviations & Data Sources \\
\hline Foreign Direct Investment & FDI stock & Ln FDI & World Bank \\
\hline Market Size & GDP & Ln MS & World Bank \\
\hline Trade Openness & Percentage of GDP & TO & World Bank \\
\hline Labor Force & Labor Force & Ln LF & World Bank \\
\hline Telecommunication & Mobile cellular & TELE & World Bank \\
Infrastructure & subscriptions & & \\
\hline
\end{tabular}

\section{Foreign Direct Investment}

According to World Bank, FDI is the amount of net investment from foreign countries. FDI inflow in each member country of ASEAN is used in this study. FDI is taken as dependent variable. The data in the form of units of dollars and then transformed into natural logarithm. Variables are transformed into natural logarithms to approximate the normal distribution.

\section{Market Size}

Market Size generally remains the most dynamic and vital determinant for locating FDI (Mughal \& Akram, 2011). According to the World Bank, GDP is the amount of revenue earned by a country. Gross Domestic Product current US\$ is used as a proxy for market size. Therefore, a positive relationship is assumed between market size and FDI.

\section{Trade Openness}

According to the World Bank, trade openness is measured by the ratio between trading volume and nominal GDP. Trade openness is the sum of exported of goods and services and imports of goods and services divided by nominal GDP. The variable unit of trade openness is percent. Exports refers to the goods sold to other economies and imports represent the goods which an economy takes from other countries (Nasir, 2015). A positive impact is expected on FDI inflow. 


\section{Labor Force}

The labor force refers to working-age population (age 15 and older) who is economically active and produces goods/services over a period of time (World Bank, 2015). The variable unit of labor is people and transformed into natural logarithm. The relationship between labor force and FDI inflow is assumed to be positive.

\section{Telecommunication Infrastructure}

Based on data from the World Bank, telecommunications infrastructure is measured by the number of mobile cellular subscriptions. Mobile cellular subscription describes the density of telecommunications within a country (Shah, 2014). The indicator is derived by dividing the number of cell phone subscriptions by the number of population and multiplied by one hundred. Mobile cellular subscriptions measured as the \% of population (World Bank, 2015). Novianti et al. (2014) also used mobile cellular subscription as measure for telecommunication infrastructure. Positive relationship is assumed between telecommunication infrastructure and FDI inflow.

\section{Result and Discussion}

The objective of this study was to investigate empirically the factors of affecting FDI in ASEAN. Table 2 shows the regression result of the study.

Table 2: Regression results

\begin{tabular}{ccccccc}
\hline Ifdi & Coef & Std. Err. & $\mathbf{z}$ & \multicolumn{1}{c}{$\mathbf{P}>|\mathbf{z}|$} & \multicolumn{2}{c}{ [95\% Conf. Interval] } \\
\hline Ilf & .181111 & .0903455 & 2.00 & 0.045 & .0040372 & .3581848 \\
\hline infr & .0042594 & .0021149 & 2.01 & 0.044 & .0001143 & .0084045 \\
\hline Igdp & .6768663 & .1103493 & 6.13 & 0.000 & .4605856 & .8931471 \\
\hline tI & .6642254 & .1183262 & 5.61 & 0.000 & .4323104 & .8961404 \\
\hline cons & .6364282 & 1.758217 & 0.36 & 0.717 & -2.809614 & 4.08247 \\
\hline
\end{tabular}

In table 2 using random effect panel estimation. The result presented in table 2 show that all the variables were significant at $1 \%$ and $5 \%$ level of significance. The variable of labor force is positive and significant as expected. This result represents that one percent increase in labor force increases FDI by $0.18 \%$. The high of productivity will make lower unit cost so that unit price of the company is be able to compete in the global market. The development of technology can also improve the competitiveness of labor productivity. The rapid technological development is the support of increasing labor productivity (Umoru \& Yaqub, 1987). The use of production with modern technology is more efficient and can accelerate the work force in the work, resulting in more productivity. Increased labor productivity will encourage the acceleration of economic growth. Improved economic development conditions will make foreign investors to invest their capital. This result consistent with the result of Gharaibeh (2015) who found that an increase in the labor force increases the amount of FDI inflows into the country.

Telecommunication infrastructure is positive and significant at $5 \%$ significance level. The result represents that one percent increase in telecommunication infrastructure increases FDI by $0.004 \%$. Telecommunication infrastructures make companies in ASEAN countries enables to increase production activities more quickly, efficiently and effectively. This because the communications delivered between companies in ASEAN is done without meeting directly. So, it can help the companies to make decisions more precisely and can increase productiv- 
ity. If the company meets directly to decide the policy is not effective and efficient. Therefore, with the development of telecommunication productivity is expected to produce high and encourage more FDI inflow. This result consistent with the result of (Zeb et al., 2014) who found that telecommunication infrastructure as the determinants of FDI. Similarly, this result is consistent with the finding of Shah (2014) who shows that the availability of telecommunication infrastructure positively influences overseas investors location choice.

Gross Domestic Product (GDP) as a proxy for market size is positive and significant as expected. The result represents that one percent increase in GDP increases FDI by $0.67 \%$. GDP as proxy for market size in ASEAN tends to increase from year to year. A large ASEAN market needs efficient resource utilization and economic scale exploitation. The broad market size in ASEAN provides more opportunities to increase product sales as well as the profits of foreign companies so that it attracts more FDI inflow to ASEAN. This result consistent with the result of Mughal \& Akram, (2011) who found that market size as the most dominating positive impact factor to attract FDI. Nasir (2015) also show that market size significant and positively correlates with FDI.

Trade openness is positive and significant at $1 \%$ significance level. The result represents that one percent increase in telecommunication infrastructure increases FDI by 0.66 $\%$. Trade openness will provide benefits for a country in expanding broader market access. The era of trade openness seeks to eliminate trade barriers can increase exports but on the other hand can also increase imports. Trade openness will affect the trade balance. It should also be understood that trade openness does not always give advantages shown by the domestic industry will lose competition with quality foreign products and can create imbalance between countries. A country has not yet conducted a trade openness, so the relative price of the capital intensive good of the domestic country is lower than the relative price of the capital intensive good worldwide, so the implementation of trade openness will lead to an increase in the relative price of the capital intensive good domestic state (Dutt et al., 2007). This result consistent with the result of Gharaibeh (2015) and Zeb et al. (2014) who found that trade openness has significant impact on FDI. Similarly, Shah \& Khan, (2016) explained that trade and investment liberalization has a positive impact on FDI inflows.

\section{Conclusion}

Based on the regression result indicated that the four independent variables namely telecommunication infrastructure, market size, trade openness and labor force have a significant and positive influence on FDI in ASEAN. This shows that the four variables are important in attracting foreign investors to invest in the country. The easier access to telecommunications in a country will lower the cost of coordination between the parent company and its affiliates. So the better telecommunication network will attract foreign investment. Market size is positively related to FDI, indicating that the wider market size will give benefit for foreign investors to make more sales of their products. In addition, trade openness in a country will reduce the barriers that will increase production costs. This will be a draw for foreign investors. The large number of labor force also influences the flow of FDI in ASEAN.

\section{References}

Appleyard, D. R., Field, A. J., \& Cobb, S. L. (2008). International Economics. McGraw-Hill.

Azam, M. (2010). Economic determinants of foreign direct investment in Armenia, Kyrgyz Republic and Turkmenistan: Theory and evidence. Eurasian Journal of Business and Economics, 3(6), 27-40. 
Berg, C., Hansen, J., \& Sellin, P. (2004). The financial accelerator and corporate investment. Sveriges Riksbank Economic Review., 23-46.

Botrić, V., \& Škuflić, L. (2006). Main determinants of foreign direct investment in the southeast European countries. Transition Studies Review, 13(2), 359-377.

Calderón, C., \& Servén, L. (2008). Infrastructure and economic development in Sub-Saharan Africa.

Carbaugh, R. J. (2015). International Economics (15th ed.). Cengage Learning.

Chakrabarti, A. (2001). The Determinant of Foreign Direct Investment: Sensivity Analysses of Cross-Country Regression. Kyklos, 54(1), 89-114.

Demirhan, E., \& Masca, M. (2008). Determinants of foreign direct investment flows to developing countries: A cross-sectional analysis. Prague Economic Papers, 4(4), 356-369.

Dutt, P., Mitra, D., \& Ranjan, P. (2009). International trade and unemployment: Theory and cross-national evidence. Journal of International Economics, 78(1), 32-44.

Gharaibeh, A. M. O. (2015). The determinants of foreign direct investment-empirical evidence from Bahrain. International Journal of Business and Social Science, 6(8), 94-106.

Grigg, N. (2000). Infrastructure System Management \& Optimazation. Working Paper of Internasional Civil Engineering Departement Diponegoro University.

Huggins, C. E. (2007). Macroeconomics, politics, and policy: The determinants of capital flows to Latin America.

Hymer, S. H. (1960). The international operations of national firms, a study of direct foreign investment [PhD Thesis]. Massachusetts Institute of Technology.

Kurniati, Y., \& Prasmuka, A. Y. (2007). Determinan FDI (Faktor-faktor yang menentukan Investasi Asing Langsung). Working Paper WP/06/2007. Bank Indonesia.

Mughal, M. M., \& Akram, M. (2011). Does market size affect FDI? The Case of Pakistan. Interdisciplinary Journal of Contemporary Research in Business, 2(9), 237-247.

Nasir, S. (2015). FDI in India's Retail Sector: Opportunities and Challenges. Middle-East Journal of Scientific Research, 23(3).

Novianti, T., Rifin, A., Panjaitan, D. V., \& Sri Retno, W. (2014). The Infrastructure's Influence on the Asean Countries' Economic Growth. Journal of Economics and Development Studies, 2(4).

Rehman, C. A., Ilyas, M., Alam, H. M., \& Akram, M. (2011). The impact of infrastructure on foreign direct investment: The case of Pakistan. International Journal of Business and Management, 6(5), 268.

salvatore, dominick. (2013). International Economics (11th ed.). John Wiley \& Sons.

Sarna, R. (2005). The impact of core labour standards on Foreign Direct Investment in East Asia Working Paper of the Japan Institute No. 1789.

Shah, M. H. (2014). The significance of infrastructure for FDI inflow in developing countries. Journal of Life Economics, 1(2), 1-16.

Shah, M. H., \& Khan, Y. (2016). Trade liberalization and FDI inflows in emerging economies. 
Business \& Economic Review, 8(1), 35-52.

Suleiman, N. N., Kaliappan, S. R., \& Ismail, N. W. (2013). Foreign direct investments (FDI) and economic growth: Empirical evidence from Southern Africa Customs Union (SACU) countries. International Journal of Economics and Management, 7(1), 136-149.

Todaro, M. P., \& Smith, S. C. (2011). Economic Development (9th ed.). Addison Wesley.

Umoru, D., \& Yaqub, J. O. (1987). Labour productivity and health capital in Nigeria: The empirical evidence. World, 1995-2007.

Vernon, R. (1979). The product cycle hypothesis in a new international environment. Oxford Bulletin of Economics and Statistics, 41(4), 255-267.

World Bank. (2015). World development indicators 2015. The World Bank.

Zeb, N., Qiang, F., \& Shabbir, M. (2014). Telecommunication infrastructure and foreign direct investment in Pakistan: An empirical study. Global Journal of Management and Business Research. 